\title{
Penggunaan Teknik Umpan Balik dalam Pembelajaran Biologi untuk Meningkatkan Hasil Belajar Siswa Kelas X SMA Muhammadiyah Bulukumba
}

\author{
${ }^{1}$ Ernawati, ${ }^{2}$ Tri Maniarta Sari \\ Email: : www.ernaern3012@gmail.com
}

\begin{abstract}
Abstrak
Pembelajaran dengan memberikan tugas tidak akan berarti apa-apa terhadap siswa bila hanya diberikan begitu saja, sehingga perlu diberikan umpan balik, sebab dengan umpan balik siswa dapat mengetahui keunggulan dan kelemahan dalam belajar. Penelitian bertujuan untuk mengetahui peningkatan aktivitas dan hasil belajar siswa kelas X SMA Muhammadiyah Bulukumba melalui penggunaan teknik umpan balik dalam pembelajaran biologi. Penelitian tindakan kelas ini dilaksanakan dalam dua siklus yaitu siklus I dan siklus II. Subjek penelitian yakni kelas X SMA Muhammadiyah Bulukumba dengan jumlah 27 siswa. Data yang diperoleh dianalisis dengan menggunakan statistik deskriptif. Hasil penelitian menunjukkan bahwa aktivitas siswa mengalami peningkatan dari siklus 1 ke siklus II, hal ditunjukkan dengan terjadinya peningkatan persentase aktivitas siswa. Hasil belajar biologi siswa juga mengalami peningkatan di mana nilai rata-rata hasil belajar siswa pada siklus I adalah 61,73 dengan kategori sedang meningkat pada siklus II dengan nilai rata-rata 75,56 dengan kategori tinggi. Dengan demikian, dapat ditarik kesimpulan bahwa melalui penggunaan teknik umpan balik dalam pembelajaran biologi maka terjadi peningkatan aktivitas dan hasil belajar siswa kelas X SMA Muhammadiyah Bulukumba.
\end{abstract}

Kata Kuci: Aktivitas Siswa, Hasil Belajar, TeknikUmpan Balik

\begin{abstract}
Learning by giving assignments will not mean anything for students if they don't take it serious, so that needs feedback, because with feedback students can know the strengths and weaknesses in learning process. The research aims to determine the improvement in activity and learning outcomes of students of class X of SMA Muhammadiyah Bulukumba through the using of feedback techniques in biology learning. This class action research was carried out in two cycles, cycle I and cycle II. The research subjects were class X SMA Muhammadiyah Bulukumba with 27 students. The data obtained were analyzed by using descriptive statistics. The results showed that student activity was improved from cycle 1 to cycle II, this was indicated by improving in the percentage of student activity. Biology learning outcomes of students also improved where the average value of student learning outcomes in the first cycle was 61,73 with the category being improved in the second cycle with an average value of 75,56 with a high category. Thus, it can be concluded that through the using of feedback techniques in learning biology can improve in activity and learning outcomes of students of class X of SMA Muhammadiyah Bulukumba.

Keywords: Student Activities, Learning Outcomes, Feedback Techniques.
\end{abstract}

\footnotetext{
${ }^{1}$ Universitas Sembilan belas November Kolaka, Indonesia

${ }^{2}$ Universitas Sembilan belas November Kolaka, Indonesia
} 


\section{PENDAHULUAN}

Memasuki abad ke-21, sistem pendidikan nasional menghadapi tantangan yang sangat kompleks dalam menyiapkan kualitas Sumber Daya Manusia (SDM) yang mampu bersaing diera globalisasi. Upaya yang tepat untuk menyiapkan sumber daya manusia yang berkualitas dan satu-satunya wadah yang dapat dipandang dan seyogyanya berfungsi sebagai alat untuk membangun SDM yang bermutu tinggi adalah pendidikan. Untuk mencapai tujuan pendidikan nasional pemerintah telah menyelenggarakan perbaikan-perbaikan peningkatan mutu pendidikan pada berbagai jenis dan jenjang. Namun demikian fakta di lapangan belum menunjukkan hasil yang optimal. Saat ini menurut banyak pihak dan kalangan yang menilai, kualitas pendidikan di Indonesia masih berada di bawah ratarata negara berkembang lainnya. Berdasarkan hasil survei dari tahun 1997 hingga 2007 oleh World Competitiveness Year Book diketahui bahwa dari 47 negara pada tahun 1997 pendidikan Indonesia berada di peringkat ke 39. Selanjutnya di tahun 1999 berada pada peringkat ke 46 . Hasil survei di tahun 2002 Indonesia berada di urutan 47 dari 49 negara, dan pada 2007 Indonesia menempati posisi ke-53 dari 55 negara yang disurvei (Radikal, 2012).

Idealnya pendidikan seharusnya merupakan proses yang mengantisipasi dan membicarakan masa depan, tidak terfokus dan berorientasi pada masa sekarang dan masa lalu. Hendaknya pendidikan menatap jauh ke depan dan sudah saatnya berorientasi dan memikirkan pada apa yang akan dihadapi siswa dimasa mendatang. Dengan demikian permasalahanpermasalahan pendidikan yang muncul saat ini perlu mendapat perhatian. Salah satu masalah dalam pembelajaran pada pendidikan formal (sekolah) dewasa ini adalah masih rendahnya motivasi, aktivitas dan hasil belajar siswa (Slameto, 2008). Keterlibatan siswa dalam pembelajaran sesuai dengan prinsip belajar menurut teori behaviorisme yaitu pembelajaran dapat terjadi dengan baik jika siswa ikut terlibat selama proses pembelajaran secara aktif. Dalam melibatkan siswa dalam pembelajaran dibutukan suatu metode. Banyak jenis metode mengajar yang dapat diterapkan agar siswa dapat lebih meyakinkan tentang apa yang dipelajari dari guru, lebih memperdalam, memperkaya atau memperluas wawasan tentang apa yang dipelajari. Mereka berkesempatan memupuk perkembangan dan keberanian mengambil inisiatif, bertanggung jawab dan berdiri sendiri (Sagala, 2009)

Siswa akan merasakan manfaatnya jika mereka memahami apa yang dipelajari dan dapat menyelesaikan tugas yang diberikan dengan baik. Soal-soal ujian akan diselesaikan dengan mudah oleh mereka dan mendapatkan nilai yang tinggi. Siswa yang selalu mengerjakan tugas akan menciptakan suatu kebiasaan sehingga akan berdampak positif dalam kehidupan sehari-harinya (Farisatma, 2017). Tugas yang diberikan ke siswa tidak akan berarti, bila tugas hanya diberikan begitu saja dan diberikan secara terus menerus tanpa feedback atau umpan balik. Dengan demikian umpan balik perlu diberikan, sebab dengan feedback atau umpan balik, siswa dalam mengerjakan tugasnya akan dapat mengetahui keunggulan dan kelemahannya. Pengalaman yang menyenangkan bagi siswa selama belajar serta akan menjadi insentif bagi siswa, jika umpan balik yang bersifat positif diberikan (Seruni \& Hikmah, 2014) Sehingga siswa akan berkeinginan untuk mengulang dan memperoleh kembali respons yang telah diberikan (Herlina \& Diana, 2012). Pemberian penghargaan terhadap apa yang telah siswa upayakan, akan menambah motivasi dan semangat mereka untuk belajar lebih giat lagi. 
penghargaan kepada siswa berupa nilai adalah penerapan teori penguatan yang juga disebut "operant conditioning" (Sagala, 2009)

Berdasarkan uraian tersebut, maka penelitian tindakan kelas dengan menerapkan penggunaan teknik umpan balik pada pembelajaran perlu dilakukan sebagai upaya untuk meningkatkan aktivitas dan hasil belajar siswa (Rahmawati, 2009).

\section{METODE}

Penelitian yang telah dilaksanakan di SMA Muhammadiyah Bulukumba ini merupakan Penelitian Tindakan Kelas (Classroom Action Research) yang dalam pelaksanaannya terdiri atas empat tahap pelaksanaan yaitu: perencanaan, tindakan, observasi/evaluasi dan refleksi.

Variabel dalam penelitian ini adalah penggunaan teknik umpan balik dalam pembelajaran sebagai variabel bebas, aktivitas dan hasil belajar siswa kelas $X$ SMA Muhammadiyah Bulukumba sebagai variabel terikat.

Waktu pelaksanaan penelitian pada bulan Desember 2018 sampai Februari 2019 di SMA Muhammadiyah Kabupaten Bulukumba. Subjek dalam penelitian tindakan kelas ini adalah siswa kelas $X$ SMA Muhammadiyah Bulukumba Tahun pelajaran 2018/2019 dengan jumlah siswa sebanyak 27 orang.

Penelitian yang dilaksanakan di SMA Muhammadiyah ini merupakan Classroom action research atau jenis penelitian tindakan kelas yang dimana tahap awalnya adalah melakukan refleksi awal. Penelitian tindakan kelas secara garis besarnya memiliki desain dengan empat langkah utama yang terdiri atas: membuat rencana tindakan, melaksanakan tindakan observasi, melakukan evaluasi dan refleksi.

Desain penelitian tindakan kelas (PTK) adalah proses perbaikan yang sifatnya kontinu atau secara terus- menerus dari tindakan yang dilakukan yang dianggap masih memiliki kekurangan atau kelemahan (sebagaimana hasil refleksi) yang tujuannya adalah ke arah yang lebih baik. Penelitian tindakan kelas ini dilaksanakan dalam dua siklus. Pada setiap siklus dilakukan evaluasi pada proses belajar maupun hasil belajar siswa. Pelaksanaan pembelajaran masing-masing siklus berlangsung selama dua pekan pembelajaran yang terdiri 2 kali pertemuan (selama 4 jam pelajaran) yang dilaksanakan sesuai dengan perubahan atau tujuan penelitian yang ingin dicapai (Depdikbud, 2008).

Dalam penelitian ini, adapun teknik pengumpulan data aktivitas siswa dan data hasil belajar siswa yang dilakukan adalah: Data tentang proses pembelajaran yaitu aktivitas belajar yang dilakukan siswa selama proses pembelajaran berlangsung di kelas diperoleh dengan menggunakan lembar observasi aktivitas siswa (LOAS). Lembar observasi ini merupakan parameter yang bertujuan untuk mengukur tindakan/aktivitas siswa dalam proses pembelajaran yang meliputi: kehadiran siswa, menyimak penjelasan guru, menjawab pertanyaan, mengajukan pertanyaan, dan menanggapi jawaban siswa lain, tingkat keberanian atau kepercayaan diri siswa dalam mempersentasekan hasil kerjanya, serta tindakan atau aktifitas yang dilakukan siswa yang dianggap tidak sesuai/relevan dengan kegiatan pembejaran yang sedang dilaksanakan. Data mengenai hasil belajar siswa (dalam hal ini adalah peningkatan penguasaan materi belajar) diperoleh dengan membandingkan skor atau nilai siswa dari tes yang dilakukan di akhir siklus I dan siklus II. Tes hasil belajar dalam bentuk pilihan ganda (Arikunto, 2008).

Selanjutnya data yang diperoleh dianalisis dengan menggunakan analisis deskriptif kualitatif dengan menggambarkan aktivitas siswa yang 
diperoleh dari pengamatan perilakuperilaku siswa selama pembelajaran berlangsung dan menggunakan analisis statistik kuantitatif dengan mendeskripsikan hasil pengusaan kognitif atau hasil belajar biologi siswa yang diperoleh dari tes hasil belajar.

Analisis kualitatif aktifitas siswa menggunakan teknik persentase untuk tiap indikator-indikator pengamatan perilaku siswa di kelas baik pada siklus I maupun II. Untuk analisis kuantitatif hasil belajar digunakan tabel distribusi frekuensi hasil belajar, di mana data hasil belajar siswa diklasifikasikan menjadi lima kelompok kategori dengan berdasarkan pada skala angka/skor 0-100 yang distribusi frekuaensinya disajikan pada Tabel 1 di bawah ini.

Tabel 1. Interval Nilai dan Kualifikasi Hasil Belajar Siswa

\begin{tabular}{cc}
\hline Interval nilai & Kualifikasi \\
\hline $85-100$ & Sangat Tinggi \\
$70-84$ & Tinggi \\
$55-69$ & Sedang \\
$40-54$ & Rendah \\
$0-39$ & Sangat rendah \\
\hline
\end{tabular}

Sumber: Sudjana (2008)

\section{PEMBAHASAN}

\subsection{Aktivitas Siswa}

Data yang diperoleh menunjukkan bahwa tingkat aktivitas siswa selama proses pembelajaran pada siklus I menunjukkan masih kurang maksimalnya keaktifan siswa baik pada pertemuan pertama ke pertemuan dua, di antaranya adalah persentase siswa yang memperhatikan penjelasan guru yakni hanya 15 orang $(55,56 \%)$ pada pertemuan pertama dan 20 orang $(74,07 \%)$ pada pertemuan ke dua, siswa yang mempelajari atau mengerjakan tugas yang diberikan hanya 14 orang $(51,85 \%)$ pada pertemuan pertama dan 18 orang $(66,67 \%)$ pada pertemuan ke dua, demikian halnya untuk siswa yang melengkapi atau memperbaiki tugas di akhir pembelajaran sebanyak 12 orang
$(44,44 \%)$ pada pertemuan pertama dan 17 orang $(62,96 \%)$ pada pertemuan kedua. Meskipun terlihat adanya peningkatan persentase aktivitas dari pertemuan pertama ke pertemuan ke dua, tetapi peningkatan tersebut tidak signifikan (tidak maksimal).

Selanjutnya siswa yang mengajukan pertanyaan dan yang menjawab pertanyaan masing-masing dari 5 orang $(18,52 \%)$ dan 4 orang $(14,81 \%)$ pada pertemuan pertama dan masing-masing 7 orang $(25,93 \%)$ pada pertemuan ke dua, siswa yang memberikan tanggapan/komentar dari 3 orang $(11,11 \%)$ menjadi 5 orang $(18,52 \%)$.

Sedangkan, untuk indikator perilaku-perilaku yang tidak relevan dengan proses pembelajaran, masih terlihat ada siswa: berisik, keluar masuk kelas, mengantuk, melamun, atau mengganggu siswa lain yaitu 8 orang $(29,63 \%)$ pada pertemuan pertama dan 6 orang $(29,63 \%)$ pada pertemuan ke dua.

Berdasarkan hasil analisis yang diuraikan di atas, maka dapat dilihat bahwa telah terjadi peningkatan aktivitas siswa dari pertemuan pertama ke pertemuan kedua, hanya saja peningkatan tersebut tidak signifikan/tidak makssimal, sehingga dapat dinyatakan bahwa aktivitas siswa pada siklus I masih kurang maksimal dalam hal keseriusan, keantusiasan, dan partisipasi dalam kegiatan belajar mengajar.

Selanjutnya data aktivitas siswa pada siklus II menunjukkan peningkatan yang signifikan dan sangat baik dari siklus I ke siklus II yaitu untuk persentase siswa yang memperhatikan penjelasan guru mengalami peningkatan hingga $100 \%$ baik pada pertemuan pertama maupun pada pertemuan ke dua, siswa yang mengerjakan tugas dan yang memperbaiki/melengkapi tugas masingmasing dari 23 orang $(85,19 \%)$ dan 22 orang $(81,48 \%)$ pada pertemuan pertama meningkat masing-masing menjadi 27 
orang $(100 \%)$ pada pertemuan ke dua. Demikian juga untuk indikator siswa yang mengajukan pertanyaan dan yang menjawab pertanyaan meningkat masingmasing dari 10 orang $(37,04 \%)$ pada pertemuan pertama menjadi 12 orang $(44,44 \%)$ dan 14 orang $(51,85 \%)$ pada pertemuan ke dua, yang memberikan tanggapan/komentar dari 7 orang $(25,93 \%)$ pada pertemuan pertama menjadi 10 orang $(37,04 \%)$ pada pertemuan ke dua.

Sementara itu, untuk perilakuperilaku siswa yang tidak relevan dengan kegiatan belajar mengajar, misalnya siswa yang berisik, yang keluar masuk kelas selama kegiatan pembelajaran, siswa mengantuk, melamun, dan yang mengganggu siswa lain mengalami penurunan dari siklus I ke siklus II. Meskipun masih ada siswa yang berperilaku tidak relevan dengan kegiatan pembelajaran sebesar 7,40\% (2 orang) pada pertemuan pertama, tetapi untuk pertemuan kedua tidak ada lagi siswa yang memperlihatkan perilaku yang dianggap tidak sesuai/relevan kegiatan belajar yang berlangsung.

Berdasarkan uraian di atas, maka dinyatakan bahwa segala kekurangankekurangan yang ditemukan pada siklus I telah dapat diidentifikasi, dievaluasi dan diperbaiki dengan memberikan bentuk tindakan sesuai dengan jenis masalah. Sehingga dapat dianggap bahwa siklus II yang merupakan lanjutan dari siklus I mengalami peningkatan positif dalam hal aktivitas siswa selama proses pembelajaran berlangsung.

\subsection{Hasil Belajar Siswa}

Data mengenai hasil belajar siswa pada siklus I yang dikategorikan tinggi sebesar $14,81 \%$ (4 orang), yang dikategorikan sedang sebesar 59,26\% (16 orang), dan yang dikategorikan rendah sebesar $25,93 \%$ (7 orang). Sementara itu, tidak ada siswa yang dikategorikan sangat tinggi dan sangat rendah.
Hal tersebut menyatakan bahwa hasil belajar siswa pada siklus I belum maksimal (rendah) karena belum ada siswa yang masuk dalam kategori sangat tinggi, dan siswa yang masuk kategori tinggi hanya sebesar $14,81 \%$ dan masih ada siswa yang masuk kategori rendah sebesar $25,93 \%$. Selanjutnya nilai rata-rata hasil belajar siswa pada siklus I adalah 61,73 dari skor ideal 100 .

Hasil belajar siswa pada siklus II mengalami peningkatan dari siklus I. Hal ini dapat dilihat dari sudah adanya siswa yang masuk sangat tinggi dan tidak ada lagi siswa yang masuk kategori rendah. Siswa dengan kategori sangat tinggi sebanyak 5 orang $(18,52 \%)$, siswa dengan kategori tinggi meningkat dari 4 orang $(14,81 \%)$ pada siklus I menjadi 14 orang $(51,85 \%)$ dan jumlah siswa dengan nilai kategori sedang mengalami penurunan dari 16 orang $(59,26 \%)$ menjadi 8 orang $(29,63 \%)$.

Selanjutnya nilai rata-rata hasil belajar siswa pada siklus II adalah 75,56 dari skor ideal 100. Dengan demikian kategori hasil belajar siswa pada siklus II dikategorikan tinggi.

Peningkatan aktivitas siswa maupun hasil belajar siswa dari siklus I ke siklus II terjadi akibat dari proses refleksi dari penelitian tindakan kelas, karena dengan adanya suatu refleksi akan didapatkan masukan-masukan yang sangat berharga dan akurat bagi penentuan langkah-langkah berikutnya. Dalam penelitian langkah berikutnya yang dimaksud dan sangat ditekankan adalah penggunaan teknik umpan balik.

Menurut (Sudrajat, 2009), ketika umpan balik secara tepat dan berkesinambungan diterapkan maka ternyata sebagian besar siswa dapat meningkatkan prestasi belajarnya. Tidak hanya umpan balik dalam bentuk fisik yang bisa digunakan, tetapi umpan balik dalam bentuk mental juga sangat penting karena akan selalu berproses dalam memberikan dorongan, motivasi dan 
kemampuan siswa untuk meningkatkan hasil belajarnya.

Sejalan juga dengan (Rahman, 2019), yang menyatakan bahwa dampak yang baik akan terjadi pada siswa jika seorang pendidik menggunakan umpan balik positif. Karena melalui pemberian umpan balik positif siswa akan merasa bahwa guru peduli dan memperhatikannya. Siswa akan merasa jika ada orang yang memberikan dorongan untuk menjadi lebih baik. Dengan demikian siswa akan menjadi lebih rajin, lebih giat dalam melakukan kegiatan belajar. Hal itu dapat meningkatkan kemampuan belajar siswa. Karena siswa tidak hanya mengerti tentang kesalahan yang dilakukannya namun siswa juga mendapatkan dorongan dari gurunya untuk terus meningkatkan kemampuan dan membenarkan kesalahannya. Sehingga siswa dapat meningkatkan pencapaian yang dia dapat. Dengan demikian dianjurkan untuk menggunakan berbagai teknik umpan balik dalam proses pembelajaran untuk mencapai tujuan pembelajaran yang diharapkan.

\section{KESIMPULAN}

Berdasarkan hasil penelitian di SMA Muhammadiyah Bulukumba yakni penggunaan teknik umpan balik dalam pembelajaran biologi dapat disimpulkan bahwa aktivitas siswa mengalami peningkatan dari siklus 1 ke siklus II, hal ditunjukkan dengan terjadinya peningkatan persentase siswa untuk kegiatan-kegiatan yang relevan dengan pembelajaran. Hasil belajar biologi siswa juga mengalami peningkatan, dimana hasil belajar siswa pada siklus I masih ada siswa dengan kategori rendah dan belum ada siswa yang masuk dalam kategori sangat tinggi. Sedangkan hasil belajar siswa pada siklus II, tidak ada lagi siswa dengan nilai kategori rendah, dan telah tedapat siswa dengan kategori sangat tinggi.

Dengan demikian, disarankan kepada pengajar untuk menggunakan teknik umpan balik dalam pembelajaran karena hasil penelitian menunjukkan terjadinya peningkatan aktivitas dan hasil belajar siswa.

\section{DAFTAR PUSTAKA}

Arikunto, S. (2008). Prosedur Penelitian (Suatu Pendekatan Praktek). Rineka Cipta.

Farisatma. (2017). Applying Group Work to Improve Student's Grammar Achievements. Imperial Journal of Interdisciplinary Research - IJIR, 3(5), 1971-1975.

Herlina, \& Diana. (2012). Peran Umpan Balik bagi Mahasiswa Kedokteran. Jurnal Pendidikan Kedokteran Indonesia, 1(3), 151-158.

Radikal, E. (2012). Urutan Kualitas Pendidikan Indonesia Dimata Dunia Dari Tahun Ketahun. http://ekoradikal.html/13./01/2012

Rahman, F. (2019). Environmental Expression Using Discourse Analysis. IOP Conference Series: Earth and Environmental Science, 1, 343.

Rahmawati. (2009). Penerapan Pembelajaran Matematika Melalui Pemberian Tugas Terstruktur Dengan Umpan Balik Dan Cooperatif Learning Di Tinjau Dari Aktivitas Siswa.

Sagala, S. (2009). Konsep dan makna pembelajaran. Rineka Cipta.

Seruni, \& Hikmah. (2014). Pemberian Umpan Balik dalam Meningkatkan Hasil Belajar dan Minat Belajar Mahasiswa. Jurnal Formatif, Volume 4(3), 227-236.

Slameto. (2008). Belajar dan Faktor-faktor yang Mempengaruhinya. Rineka Cipta.

Sudrajat, R. (2009). Terjemahan bebas dari judul asli: Providing Students with Effective Feedback. Academic Leadership Jounal Online, 4(4). 